\title{
The Effects of Work-Life Balance Towards Work Stress Among Nurses
}

\author{
Andi Rezka Fadillah ${ }^{1 *}$, Rezky Ariany Aras $^{2}$, Sri Wahyuni ${ }^{3}$ \\ ${ }^{1}$ Psychology Department, Medical Faculty, Hasanuddin University, Indonesia \\ ${ }^{2}$ Psychology Department, Medical Faculty, Hasanuddin University, Indonesia \\ ${ }^{3}$ Psychology Department, Medical Faculty, Hasanuddin University, Indonesia \\ *Corresponding author. Email: rezkaka97@gmail.com
}

\begin{abstract}
The study aims to explain the effect of work-life balance on work stress among nurses. The respondents in this study consist of 123 nurses. The measuring instruments used to collect data in this research were the work-life balance scale and the work stress scale. Simple linear regression analysis was used in this study to test the research hypothesis. According to the data analysis results, the value of $R^{2}=0,086$ and the value of $\beta=-0,241$, which explained that work-life balance has $8,6 \%$ effects on work stress among nurses. A higher level of work-lifebalance leads to lower work stress among nurses. This research implies the importance of work-life balance knowledge and skills to minimize severe stresses among nurses who play significant roles in delivering good service in a hospital.
\end{abstract}

Keywords: Work-life balance, work stress, nurses.

\section{INTRODUCTION}

The hospital is an organization in health services for the community. The success of a hospital in carrying out its function as a health service provider to the community can be seen from the quality of services provided by the hospital [1]. A hospital with good quality is a hospital that provides professional and optimal services to the community and makes it one of the hospital's goals. One of the human resources thathas a major influence on the hospital's success is thenurse. Nursing personnel is one of the important components in health services in hospitals. Therefore, hospitals need to manage and pay attention to nurses to optimize hospital quality. Based on the basic competency standards of nurses according to PPNI [2], there are basiccompetencies set that must be possessed by every Indonesian nurse at all levels. These competencies need to be mastered by every nurse in carrying out their work.

Handoko [3] states that worker productivity dependson stress levels, job satisfaction, motivation, physical conditions of work, compensation systems, and other behaviors. In addition, workers who continuously experience high work demands can also experience obstacles in developing their abilities to achieve organizational goals [4]. Evan \& Johnson [5] states that work stress is one factor that determines the ups and downs of a person's performance.
The success of a nurse in carrying out their role can be seen from their ability to manage time, control stress both she experiences and others (patients and patients' families), and overcome conflicts that occur, both internally and externally, both individually and in groups [6]. Therefore, nurses need to maintain their physical and psychological health to carry out their roles to the fullest. When nurses experience work stress, their performance will be disrupted andhinder their work.

Handoko [3] states that work stress is a condition of tension that affects emotions, thought processes, andone's condition. Stress that is too big can interfere with a person's ability to deal with the work environment, so that it can have an impact on decreasing performance. Scientists agree that moderate levels of stress are manageable, even beneficial, and most people are equipped to handle it. However, increasing stress levels can quickly damage worker morale, poor productivity, and lower job satisfaction [7]. Stress is a problem that cannot be avoided because, in everyday life, every individual must face stress every day [7]. But it is also unavoidable by workers who work in an organization. The results of several surveys evidence this. One of them, conducted by the American Psychological Association in 2011 , found that as many as $36 \%$ of 1,546workers in America felt pressure or stress due to their work [8]. Another survey conducted by a 
health insurance company, Cigna, found that $75 \%$ of Indonesianworkers claimed to have felt stressed about their work. This shows that work stress is still quite high in workersand is an important issue to be considered by everyorganization and company [9].

Workers in the medical field prioritize providing maximum health services to each patient with limited facilities and infrastructure. It is not uncommon for doctors and nurses to experience stress [10]. Based ona survey conducted by the Indonesian National Nurses Association (PPNI) in 2006 [2], as many as $50.9 \%$ of nurses working in four provinces in Indonesia experienced work stress. Several factors can cause work stress, according to Robbins [11], the first is environmental factors consisting of economic, political, and technological uncertainty. The second factor is the individual factor, consisting of family, financial, andpersonality factors. The third factor is the organizationalfactor, which consists of task demands, role demands, interpersonal demands, organizational structure, and organizational leadership.

A survey conducted by the American Psychological Association in 2011 [8], also found that one of the factorscausing worker stress is personal life that interferes withworking hours. As many as $22 \%$ of the 1,546 workers experienced this. The low level of balance between family life and work or work-life balance can also cause stress to workers [12]. Lockwood [7] suggests that work-life balance is a state of balance between two demands where the work and life of an individual are the same. Work-life balance can be achieved when individuals experience satisfaction and balance between personal lifeand work life [13].

The existence of two roles that each worker has makes it sometimes difficult for them to share their timeand energy fairly. Another survey conducted by the Society of Human Resource Management shows that workers value family as the most important priority, but it is difficult to achieve because of the busyness of their work [14]. As a result, many workers experience role conflicts between family life and their responsibilities as workers. Dual role conflict occurs when the individual, on the one hand, has to do his job in the office and, on the other hand, also has to carry out his duties as part of the family, making it difficult to distinguish between work interfering with family life or vice versa [15]

Based on the results of interviews conducted by researchers with three nurses, it was found that nurses realized the lack of intensity of gathering with their families when one of their family members complained that they could not spend time together. In addition, nurses often feel tired after work and choose to rest after returning home, so the communication with family members is minimal. This is not in line with the work-lifebalance aspect, Work Enhancement of PersonalLife (WEPL). This dimension refers to how work can improve the quality of an individual's personal life.

One theory that can explain these two variables is theConservation of Resource Theory by Hobfoll [16]. This theory explains that individuals can experience stress when faced with a loss of resources. The resources in question are things that are valued by individuals, including conditions (marital status, family, work), personal characteristics (self-esteem, social aplomb), objects (cars, houses), and energy (time, money, knowledge) [17]. Individuals can experience stress whenthey feel threatened with losing resources and fail to obtain and maintain the resources they have [16]. When individuals experience an imbalance between work and personal life, resources such as time and energy will be lost in managing both roles. This can leadto dissatisfaction, anxiety and can moderate conflict andstress [18].

The results of previous research conducted by Fauzi [1] on female nurses who work at a hospital found a negative relationship between work-life balance and work stress. This study explains that the higher the level of work-life balance owned by nurses, the lower the level of work stress felt by nurses. Conversely, the lower the level of work-life balance owned by nurses, the higher the work stress felt by nurses. The results of other studies also show that work-life balance can be a predictor of work stress variables. The correlation between work-life balance and workstress is negative, which means that the higher the work-life balance, the lower the work stress. Conversely, the lower the work-life balance, the higher the work stress [12].

\subsection{Work-Life Balance}

Work-life balance is a state of balance in two demands where the work and life of an individual are the same [7]. Greenhaus, Collins, and Shaw [19] define work-life balance as the extent to which individuals are involved in a balanced and satisfied manner in carrying out their rolesin family and work roles. Fisher [20] argues that work-lifebalance is an effort made by individuals to balance two or more roles. Work-life balance can also be defined as satisfaction and good functioning at work and home witha minimum level of conflict [21]. In line with Clark, Frone [22] relates work-life balance to role conflict; he defines work-life balance as a low level of conflict between one's role in the family and at work.

Based on the explanation of these definitions, it can be concluded that work-life balance is a state of 
balance between the demands of work with the individual's personal life and in the family, thereby reducing the possibility of conflicts in work and personal life. Balancecan occur if individuals can create appropriate roles at work and in families with low levels ofconflict [23].

Fisher et al [24] explain the dimensions of worklifebalance, in which:

\section{a. Work Interference with Personal Life (WIPL)}

The work interference with the personal life dimension refers to how work can interfere with an individual's personal life. For example, individuals become less able to interact with their families at home because they often work overtime.

\section{b. Personal Life Interference with Work (PLIW)}

The dimension of personal life interference with work refers to the extent to which an individual's personal lifeinterferes with his work life. For example, if the individual has problems in his personal life, the individual's performance at work decreases.

\section{c. Personal Life Enhancement of Work (PLEW)}

Personal life enhancement of work refers to the extent to which an individual's personal life can improve an individual's performance in the world of work. For example, when an individual feels happy because his personal life is pleasant, it can make his mood at work.

\section{d. Work Enhancement of Personal Life (WEPL)}

The dimension of work enhancement of personal life refers to how work can improve the quality of an individual's personal life. For example, individuals can utilize the skills acquired at work in theirdaily lives.

\subsection{Work Stress}

Handoko [3] states that work stress is a condition of tension that affects emotions, thought processes, and one's condition. Ringgio [25] also explains that work stress is a physiological and psychological reaction to a work-related event that is perceived as a threat. Mangkunegara [26] states that work stress is a feeling of pressure experienced by employees in dealing with work. The stress can be identified through the symptomsshown, such as unstable emotions, being alone, having trouble sleeping, smoking excessively, not being able to relax, being anxious, tense, nervous, increasing blood pressure, and experiencing digestive disorders. Evan andJohnson [25] describe work stress as one factor that determines the ups and downs of employee performance.

Based on these definitions, it can be concluded that work stress is a reaction to the pressures obtained from the work environment and conditions that affect the emotions, thought processes, and performance of employees.

French et al. [27] describe aspects related to nurses work stress as follows:

a. Patients and their families; stress experienced by nurses can arise due to interactions between nurses andpatients and their families. Kamal [6] explains that the stress experienced by nurses can be caused by thedemands of the patient's needs and complaints from thepatient's family.

b. Workload; which can also be one aspect of the emergence of work stress for nurses. The workload includes the number of tasks, staffing, scheduling issues, and time constraints.

c. Problems with supervisor include the nurse's experience of dealing with conflict, criticism, orlack of support from direct supervisors, nursing administrators, and other health administrators.

d. Treatment uncertainty, stress experienced by nurses can also arise due to a lack of freedom and independence in decision-making. Kamal [6] suggests that most nurses sometimes feel unable to make decisions and are powerless to change unsatisfactory situations.

e. Conflict with doctors, Kamal [6] explains that nurses periodically face emotional situations and intenseinterpersonal and interprofessional situations and conflicts in the workplace while trying to make safe and appropriate decisions.

f. Death and dying, caring for critically or dying patients, are some of the things that nurses will face. Brisley and Wood [6] suggest that the experience of dealing with dying patients often causes anxiety for nurses.

g. Discrimination, this aspect includes gender, race, and ethnic discrimination. Nurses who face discrimination can cause stress for nurses.

h. Problems with co-workers, one of the triggers of workstress, can also cause by the nurse's social relationshipwith her co-workers. It is also related to the lack of opportunity to share experiences with other nurses anddifficulties in working with certain nurses.

i. Inadequate preparation, feelings of not being adequately prepared to help the patient and family's emotional needs, and not being able to 
properly answerthe patient's questions are triggers stress for nurses.

\section{METHOD}

The research type used in this research is quantitativeresearch along with the non-experimental research type. The independent variable is work-life balance in this study, and the dependent variable is work stress. The subjects of this study consisted of 123 hospital nurses.

The data collection method in this study used a psychological scale. The scale in this study is the Work-Life Balance Scale and the Work Stress Scale. The formof the data used is a Likert measurement scale. The work-life balance scale used in this study is the work-life balance scale of Fisher et al. [24], which was adapted by Umar [28]. The dimension of work-life balance consists of aspects, such as Work Interference with Personal Life(WIPL), Personal Life Interference with Work (PLIW), Personal Life Enhancement of

Table 1. Simple Linear Regression Analysis
Work (PLEW), dan WorkEnhancement of Personal Life (WEPL). The Work-Life Balance Scale has 17 items, the favorable items are madeup of 6 items, and the unfavorable items are made up of 11 items.

The work stress scale used in this study is the NursesWork Stress Scale of French et al. [27], adapted by Buranda [6]. Dimensions of work stress are patients and their families, workload, problems with supervisors, the uncertainty of treatment, conflict with doctors, death and dying, discrimination, problems with colleagues, and inadequate preparation. The Nurse Work Stress Scale consists of 37 items, the favorable items are made up of 31 items, and the unfavorable items are madeup of 6 items.

\section{RESULT AND DISCUSSION}

Based on the hypothesis in this study, a linear regression analysis was carried out with the results shown in Table 1.

\begin{tabular}{cccccccc} 
Variable & $\mathrm{R}$ & $\mathrm{R}^{2}$ & $\mathrm{~F}$ & $\mathrm{Sig} . \mathrm{F}$ & $\mathrm{B}$ & $\mathrm{t}$ & Sig.t \\
\hline $\begin{array}{c}\text { Work-Life } \\
\text { Balance }\end{array}$ & -0.294 & 0.086 & 1,238 & 0.001 & $-0,241$ & $-3,383$ & 0,001 \\
\hline
\end{tabular}

Note: Dependent Variable: Work-Stress, $\mathrm{n}=123, \mathrm{~B}=$ Unstandardized Beta Weight

The results show that the significance value of $\mathrm{F}$ is smaller than 0.05 (sig. $<0.05$ ), which is 0.001 . This valueindicates a significant effect of work-life balance on work stress, which means that the hypothesisin this study is accepted. The regression test show that the work-life balance variable has an effectof $8.6 \%$ on the work stress of nurses. This supports several previous studies, which also found that work-life balance has a negative influence and relationship on work stress [1][29][30]. Narendra \& Saraswati [12] stated that work-life balance can be a predictor variable for work stress variables.

The results of this study are in line with research conducted by Fauzi [1], which found that there is a negative relationship between work-life balance and work stress in female nurses. Based on the research results, it is known that work-life balancehas an effect of $35.88 \%$ on work stress in female nurses. This shows that the higher the level of work-life balance owned by the nurse, the lower the level of work stress felt by the nurse.

Nurses who balance personal life and work are proven to significantly reduce work stress levels. Select [31] explains that individuals have a good work- life balance if they can fulfill work and family commitments and fulfill responsibilities outside of work. If individuals can fulfilltheir responsibilities in work, family, and other things ina balanced way, it can be ascertained that the worker has a good level of work-life balance [12].

On the other hand, if the individual experiences an imbalance between his personal life and work that causes role conflict, it can lead to stress [16]. Schermerhorn [32] explains that individuals need to have the ability to manage the time needed in both roles they have, if the individual needs and demands have been met, it can be said that the individual has a work-life balance. Nurses who can fulfill their responsibilities in the family will feel calm in doing their jobs. They will not feel disturbed when working if all their tasks at home are completed before leaving for work. Nurses will carry out their duties without feeling a burden or pressure outside of work.

Furthermore, the relationship between work-life balance and work stress can be explained using the Conservation of Resources Theory. Conservation of Resources theory explains that stress can occur when individuals experience three states: the threat of losing 
resources, losing resources, and failing to regain lost resources after making significant efforts [16]. The resources in question are things that are valued by individuals, including conditions (marital status, family, work), personal characteristics (self-esteem, etc.), objects(cars, houses), and energy (time, money, knowledge) [17].

When individuals experience an imbalance between work and personal life, resources such as time and energywill be lost in the process of managing both roles. This can lead to dissatisfaction, anxiety and can moderate conflict and stress [18]. Nurses who feel there is animbalance between their personal life and work can allowthem to invest their time and energy in balancing the two roles.

If nurses fail to maintain both roles, it will cause stress for nurses because they lose their resources. However, if nurses can maintain their resources, the conflict between work and family will be low, and work stress will also be below [33]. Increased role conflict can bea pressure for individuals because it will affect the individual's choice to stay or leave his job to maintain his marital and family status [34]. Thus, it is important to maintain the available resources to minimize the emergence of role conflicts that can cause stress for nurses.

The effect of work-life balance on nurses' work stress is $8.6 \%$. This can also be seen from the two variables that are in the high category. This amount shows that $92.4 \%$ is influenced by other factors outside the variables studied. Other factors affecting work stress are social support, workload, job satisfaction, and self-esteem $[12,25,35,36]$.

In addition, this study also found a difference in the mean of the work stress level scores onthe respondents in terms of marital status. In this case, themean value of the unmarried nurse group was 121.77, while the married nurse group obtained a mean value of 126.60 . These results indicate that married nurses have ahigh level of stress than unmarried nurses. This is in line with Vierdelina [37] research, which found that work stress mostly occurred in married respondents compared to unmarried respondents. This is due to problems that often occur in the family. Family conditions require special attention, for example,when a spouse or child is sick, while nurses must continue to work so that it can be stressful for nurses who are already married. This is also supported by Santrock [38] which states that family can be one of the factors that can trigger stress. Fauzi [1], in his research, also explains that when nurses work on night shifts in the morning, they also have to take care of housework such as taking care of children and so on, so that lack of rest makes nurses feel tired at work and causes work stress.

\section{CONCLUSION}

Based on the results obtained from this study, it can be concluded that there is an effect of work-life balance towards work stress among nurses. The results showed an effect of the level of work-life balance towards work stress of $8.6 \%$. Therefore, the hypothesis of this study is accepted. This study also found an effect between levels of work stress seen from marital status, where married nurses had higher levels ofwork stress than single nurses.

\section{REFERENCES}

[1] Fauzi, R. Hubungan Antara Work Life Balance Dengan Stres Kerja Pada Perawat Wanita [undergraduate thesis]. Universitas Islam Indonesia.2018.

[2] Persatuan Perawat Nasional Indonesia (PPNI). Standar Kompetensi Perawat Indonesia. Bidang Organisasi PP-PPNI: Jakarta. 2012.

[3] Handoko, TH. Manajemen Personalia Sumber Daya Manusia, Edisi Kedua. Yogyakarta: BPFE. 2008.

[4] Nahrgang JD, Morgeson FP, Hofman DA. Safety at Work: A Meta-Analytic Investigation of the Link Between Job Demands, Job Resources, Burnout, Engagement, and Safety Outcomes. Journal of Applied Psychology. 2011; 96(1): 71.

[5] Evan GW, Johnson, D. Stress and Open Office Noise. Journal of Applied Psychology. 2000; 85(5):779-783.

[6] Buranda GF. Hubungan Stres Kerja dengan PerilakuPresenteeism Perawat Rumah Sakit X Makassar [undergraduate thesis]. Universitas Negeri Makassar.2016.

[7] Lockwood NR. Work/Life Balance: Challenges and Solutions. SHRM Research Quarterly. 2003.

[8] Interactive. Stress in the Workplace: Survey Summary. American Psychological Association.2011.

[9] Cahya KD. Secara Global, Tingkat Stres Orang Indonesia Disebut Paling Rendah [Internet]. 2018 Sept 7 [Cited 2019 June 2]. Available from:

https://lifestyle.kompas.com/read/2018/07/09/193

$\underline{00} \quad$ 0820/secara-global-tingkat-stres-orang- 
indonesia- $\underline{\text { disebut-paling-rendah?page }=\text { all }}$

[10] Natasya B. Hubungan Stres Kerja Dengan Kinerja Dokter Muda Jada Ada Instalasi Rawat Darurat Rumah Sakit Wahidin Sudirohusodo [undergraduate thesis]. Unversitas Negeri Makassar. 2014.

[11] Robbins SP, Judge, TA. Essentials of Organizational Behavior, fourteenth edition. England: Pearson Education Inc. 2018.

[12] Nurendra AM, Saraswati, MP. Model Peranan Work-Life Balance, Stres Kerja dan Kepuasan KerjaPada Karyawan. Humanitas. 2016; 13(2): 84-94.

[13] Saina IV, Pio RJ, Rumawas W. Pengaruh WorkLife Balance dan Kompensasi Terhadap Kinerja Karyawan Pada PT PLN (Persero) Wilayah Suluttenggo Area Manado. Jurnal Administrasi Bisnis Unsrat. 2016; 4(3).

[14] Intan. Work-Life Balance Pada Wanita yang Bekerja. Psikologi Industri dan Organisasi. Universitas Pembangunan Jaya. 2017.

[15] Frone MR., Russell M, Cooper ML. Relationship Between Job and Family Satisfaction: Causal or Noncausal Covariation?. Journal of Applied Psychology. 1992; 77(1): 6578.

[16] Hobfoll SE. Conservation of Resources: A New Attempt at Conceptualizing Stress. American psychologist. 1989; 44(3): 513.

[17] Golembiewski RT. Handbook of Organizational Behavior, Revised and Expanded. New York: Marcel Dekker, Inc. 2000.

[18] Hobfoll SE. The influence of culture, community, and the nested-self in the stress process: advancing conservation of resources theory. Applied psychology. 2001; 50(3): 337421.

[19] Greenhaus JH, Collins KM, Shaw JD. (2003). The relation between work-family balance and quality oflife. Journal of vocational behavior. 2003; 63(3): 510-531.

[20] Fisher GG. Work/Personal Life Balance: A Construct Development Study. ProQuest Dissertations and Theses. 2001.

[21] Clark SC. Human Relations. Work/family border theory: A new theory of work/family balance. 2000;53: 747-770.

[22] Frone MR. Work-family balance. Handbook of occupational health psychology. 2003; 7: 143-162.
[23] Purohit M. A Comparative Study of Work-Life Balance in Various Industrial Sectors In Pune Region. International Journal of Marketing, Financial Services and Management Research. 2013;2(3): 198-206.

[24] Fisher G, Bulger C, Smith C. Beyond Work and Family: A Measure of Work/Nonwork Interference and Enhancement. Journal of Occupational Health Psychology. 2009; 14(4): 441-456.

[25] Almasitoh UH. Stres kerja ditinjau dari konflik peran ganda dan dukungan sosial pada perawat. Psikoislamika: Jurnal Psikologi dan Psikologi Islam.2011; 8(1).

[26] Tunjungsari P. Pengaruh Stress Kerja terhadap Kepuasan Kerja Karyawan pada Kantor Pusat PT. Pos Indonesia (Persero) Bandung. Jurnal UniversitasKomputer Indonesia. 2011; 1(1): 114.

[27] French SE, Lenton R, Walters V, Eyles J. An empirical evaluation of an expanded nursing stress scale. Journal of nursing measurement. 2000; 8(2):161-178.

[28] Umar. Kontribusi Work Life Balance Terhadap Kepuasan Kerja Pada Polwan Berstatus Menikah Di Markas Kepolisian Daerah (MAPOLDA) Sulawesi Selatan [undergraduate thesis]. Unversitas Hasanuddin Makassar. 2019.

[29] Budaya AA. Pengaruh Work Life Balance Terhadap Work Stress Pada Anggota Polisi di Polres Kediri [undergraduate thesis]. Universitas Islam Negeri Maulana Malik Ibrahim. 2008.

[30] Utomo C, Djastuti I, Mahfudz M. Pengaruh Keseimbangan Kehidupan-Kerja Terhadap Stres Kerja Yang Berimplikasi Pada Kinerja Pegawai (Studi Pada Bpk Perwakilan Provinsi Jawa Tengah) [Doctoral Dissertation]. Universitas Diponegoro. 2016.

[31] Delecta P. International Journal of Current Research: Work-Life Balance. 2011; 3(4): 186189.

[32] Schermerhorn JR., Hunt JG, Osborn RN. Organization Behavior: $9^{\text {th }}$ Edition. United States of America: John Wiley \& Sons, Inc. 2005.

[33] Saraswati VP, Subudi M. Pengaruh Konflik Pekerjaan-Keluarga dan Stres Kerja Terhadap Turnover Intention. E-Jurnal Manajemen Unud.2017; 6(6). 
[34] Nohe C, Sonntag K. Work-Family Conflict, Social Support, And Turnover Intentions: A Longitudinal Study. Journal Of Vocational Behavior. 2014; 85(1):1-12.

[35] Grandey AA, Cropanzano R. The conservation of resources model applied to work-family conflict and strain. Journal of Vocational Behavior. 1999; 54: 350-370.

[36] Khairani N. Hubungan antara Keseimbangan Kehidupan Kerja dengan Kelelahan Kerja pada Perawat Wanita yang Telah Menikah. 2018.

[37] Vierdelina, N. Gambaran Stres Kerja dan Faktor- Faktor yang Berhubungan pada Pengemudi Bus Patas 9B Jurusan Bekasi Barat-Cililitan. Jakarta. Universitas Indonesia. 2008.

[38] Martina A. Gambaran tingkat stres kerja perawat diruang rawat inap rumah sakit paru Dr. Moehammad Goenawan Partowidigdo Cisarua Bogor [undergraduate thesis]. Universitas Indonesia. 2012. 